\section{Ralph Bunche Program Suspended for Summer}

The Ralph Bunche Summer Institute was not held this summer. This program, established nine years ago, selects 10-25 AfricanAmerican rising seniors in a nationwide competition to take two graduate-level courses and to be introduced to the life of scholarship.

The Institute has been hosted by two consortia. For the first four years, it was held in Baton Rouge under the leadership of Jewel Prestage of Southern University and Peter Zwick of Louisiana State University. The Institute subsequently moved to Atlanta, Georgia, where five schools, Spelman College, Emory University, Georgia State University, Morehouse College, and Clark Atlanta University, cooperated in creating the program, led by Lois Moreland and Jeanne Meadows, both of Spelman.

Funding for the Institute has come from a variety of direct and indirect sources. The Ford Foundation, the Coca-Cola Foundation, and the U.S. Department of Education have provided major support. In addition, Emory University, Louisiana State University, Georgia State University, Spelman College, and APSA have contributed significant in-kind assistance. All told, over $\$ 600,000$ in cash and an approximate $\$ 200,000$ in in-kind gifts have been raised for this program.

While the Institute is short of funds this year, the Coca-Cola Foundation is anticipating contributing next year and the Atlanta Consortium will likely host the program for the summer of 1995. APSA is moving to find new sources of support for the Institute.

The leaders and teachers of the Atlanta Summer Institute will be honored at the nightcap reception of the Committee on the Status of Blacks in the Profession at APSA's Annual Meeting in New York on Friday, September 2, at 10:00 p.m. The honorees include

$\begin{array}{ll}\text { Lois B. Moreland } & \text { Zadie Long } \\ \text { Jeanne T. Meadows } & \text { Alan Abramowitz } \\ \text { Marilyn Davis } & \text { Courtney Brown }\end{array}$

Micheal Giles George Jones Harvey Klehr Eleanor Main Scott Taylor

Andrea Simpson

\section{APSA Establishes the Ithiel de Sola Pool Lectureship}

The Association has received a gift to endow a lecture as a memorial to Ithiel de Sola Pool. The Political Communications Organized Section supported establishing this award in recognition of Ithiel Pool, who died in 1984. The Council accepted the gift and approved an award:

The Ithiel de Sola Pool Lecture will be given every third year at the APSA Annual Meeting by a scholar selected to explore the implications of research on the issues of politics in a global society. Evoking the broad range of scholarship pursued by Ithiel de Sola Pool, the presentation may draw from among many fields, including political theory, political behavior, political communication, science and technology policy, and international affairs.

The award will convey a $\$ 1,000$ prize. A committee appointed by the APSA president in the year the lecture is given will select the award winner. The first Ithiel de Sola Pool Lecture will be given at the 1995 Annual Meeting in Chicago. The 1995 Pool Award Committee comprises Bernard C. Cohen, University of WisconsinMadison, Chair; Samuel Popkin, University of California, San Diego; and Myron Weiner, Massachusetts Institute of Technology.

Ithiel Pool received a $\mathrm{Ph}$.D. from the University of Chicago in 1952. He held academic positions at Hobart College and Stanford University before joining the MIT faculty in 1953 where he was the first chair of the political science department and a founder of the Center for International Studies. He remained a leader of MIT's political science and international programs until his death in 1984.

"Ithiel Pool was one of the outstanding political scientists of our time and a pioneer in the field of social and political communication. ... What came to interest him most were the ways in which the world has been changing and the methods by which these changes could be identified and in part measured." Thus, Karl Deutsch characterized Ithiel Pool's scholarly achievements and interests in a memorial written for $P S$ (fall 1984, pp. 841-2). Moreover, colleagues and students valued the courtesy, patience, and kindness he conveyed in his professional and personal relationships.

Jean Pool, in expressing appreciation for the wide range of subjects included in the award, noted that Ithiel Pool " . . .was always interested in interdisciplinary research, and being at MIT, the opportunity to work with mathematicians, engineers, and computer scientists was very present." She commented that a lectureship also reflected qualities attributed to him: "passion and reason" (David Bell) and as "original and surprising" (Nathan Lester).

Ithiel de Sola Pool's papers are in the archives at MIT, the Smithsonian Institution, and the University of Chicago. A bound, annotated bibliography by Lloyd Etheridge of his extensive scholarship is in the MIT library. Among his notable books are Communication in Political Development (1962), written with Gabriel Almond, Lucian Pye, Joseph La Palombara, and others; American Business and Public Policy (1963), written with Raymond Bauer and Lewis Dexter, which won the APSA's Woodrow Wilson Award in 1963; Candidates, Issues, and Strategies (1964), with Robert Abelson and Samuel Popkin; The Social Impact of the Telephone (1977), and a reader, Technologies of Freedom (1983).

\section{The Charles E. Merriam Award Reinstated}

A fund-raising drive to reinstate the Charles E. Merriam Award by assuring an endowment sufficient to support a biannual award has succeeded. This effort has been led by Gabriel A. Leiserson and David B. Truman, who formed the Merriam 
Endowment Task Force. Donations from the following people, made in response to an appeal this past spring from the Task Force, provided the funds needed to endow the award.

$\begin{array}{ll}\text { Samuel H. Barnes } & \text { Donald R. Matthews } \\ \text { Thad L. Beyle } & \text { John F. Miller } \\ \text { Fred G. Burke } & \text { Warren E. Miller } \\ \text { Karl H. Cerny } & \text { Burton B. Moyer, Jr. } \\ \text { Carl Q. Christol } & \text { Walter F. Murphy } \\ \text { William Y. Chuko } & \text { Stuart Nagel } \\ \text { Bernard C. Cohen } & \text { Dalmas H. Nelson } \\ \text { Weldon Cooper } & \text { Grady Harrison Nunn } \\ \text { Paul T. David } & \text { Robert A. Packenham } \\ \text { B. Vincent Davis, Jr. } & \text { Thomas Payne } \\ \text { Heinz Eulau } & \text { Suzanne Toll Peltason } \\ \text { David S. Fellman } & \text { Nelson W. Polsby } \\ \text { H. Schuyler Foster } & \text { Henry J. Pratt } \\ \text { Stanley T. Gabis } & \text { C. Herman Pritchett } \\ \text { Henry C. Galant } & \text { J. Austin Ranney } \\ \text { Herbert Garfinkel } & \text { Ross Rice } \\ \text { Ralph M. Goldman } & \text { Richard Rose } \\ \text { Esther S. Goldstein } & \text { Alan Rosenthal } \\ \text { Henry F. Goodnow } & \text { Stanley Rothman } \\ \text { Harold F. Gosnell } & \text { Francis E. Rourke } \\ \text { Doris Graber } & \text { Robert Scigliano } \\ \text { Fred I. Greenstein } & \text { Harold Seidman } \\ \text { Luther Gulick } & \text { Roberta Sigel } \\ \text { John Hazard } & \text { Dorothea P. Simon } \\ \text { Ferrel Heady } & \text { Herbert A. Simon } \\ \text { Alexander Heard } & \text { Rex J. Swartz } \\ \text { Pendleton Herring } & \text { Richard N. Swift } \\ \text { Samuel P. Huntington } & \text { Ross Talbot } \\ \text { Marian D. Irish } & \text { David B. Truman } \\ \text { Charles O. Jones } & \text { Vernon Van Dyke } \\ \text { Max M. Kampelman } & \text { A.J. “Jack” Wann } \\ \text { David C. Knapp } & \text { Myron Weiner } \\ \text { Peter J. Kosiba } & \text { James Q. Wilson } \\ \text { Howard Lentner } & \text { Frederick M. Wirt } \\ \text { David M. Levitan } & \text { Deil S. Wright } \\ \text { Arend Lijphart } & \text { K. E. Womack, Jr. } \\ \text { Madelon M. Loucks } & \text { Sidney Verba } \\ & \\ & \end{array}$

The Charles E. Merriam Award is given ". . . to the person whose published work and career represent a significant contribution "to the art of government through the application of social science research'."

Charles Merriam's career in the first half of this century exemplified this combination of innovative political and social science scholarship, and practical service to community and nation. The department he chaired in the $1920 \mathrm{~s}-40$ s set the agenda of the political science profession in the post-World War II decades. He was the key figure in the founding of the Social Science Research Council and its chair in its first decades. His public service included membership in the Chicago City Council, on President Hoover's Recent Social Trends Commission, President Franklin Roosevelt's National Resources Planning Board, and the Committee on Administrative Management.

The Merriam Award recipients from 1975 through 1987 were

Aaron Wildavsky, 1975

Alice M. Rivlin, 1976

James Q. Wilson, 1977

Don K. Price, 1978

E. Pendleton Herring, 1979

Evron M. Kirkpatric, 1980

Harold F. Gosnell, 1981

Richard E. Neustadt, 1982

Jack Peltason, 1983

George F. Kennan, 1984

James L. Sundquist, 1985

Thomas Cronin, 1986

Richard Nathan, 1987

A Merriam Award honoree will be announced at the 1995 Annual Meeting in Chicago. Nominations can be sent to the Selection Committee members, who are Twiley Barker, University of Illinois, Chicago, Chair; John Kingdon, University of Michigan; and Jack Levy, Rutgers University.

\section{Jones Selects Finifter As APSR Editor}

President Charles O. Jones has selected Ada W. Finifter, professor at Michigan State University, to become the next Managing Editor of the American Political Science Review. Finifter will succeed Bingham Powell, Jr., pending approval by APSA's Council at its August 31 meeting.

Finifter's term is scheduled to begin in the summer of 1995, at which time she will begin receiving submissions. Powell's last issue will be December 1995 .

Jones was guided in his choice of Finifter by a search committee chaired by President-Elect Sidney Verba. The other members of the committee included Leon Epstein, University of Wisconsin-Madison; Jean Bethke Elshtain, Vanderbilt University; John Hibbing, University of Nebraska; Matthew Holden, University of Virginia; Keith Kreh- biel, Stanford University; Powell, University of Rochester; Kay Schlozman, Boston College; and Jones (ex officio), University of Wisconsin-Madison.

The committee began its work by soliciting nominations for Managing Editor throughout the profession. A group of finalists was invited to write a letter to the committee indicating interest in the position and describing how he or she would handle the editorship. Six scholars responded.

The search committee was sufficiently impressed by the ideas articulated by the finalists that they asked APSA staff to extract portions of the letters from each and pass them on to whoever became editor. Verba and Jones, reflecting the consensus of the committee, expressed confidence in the ability of each of the finalists to edit the Review capably and fairly.

"I have tremendous confidence in Ada Finifter," Jones said in announcing his choice. "In addition to her demonstrated managerial and editorial skills, she has the admirable quality of caring deeply about the profession. The Review is in good hands, as it has been with the fine service of Bing Powell."

Finifter is editor of the widely read Political Science: State of the Discipline (1983) and the completely new volume Political Science: State of the Discipline II (1993). The articles from the first book originated from specially commissioned papers at the 1982 Annual Meeting on the state of the discipline under her direction as Program Chair.

Finifter is a scholar of American government and politics, and comparative public opinion, electoral behavior and political psychology. She is well known for her work on political alienation. Her most recent $A P S R$ article, "Redefining the Political System of the USSR: Mass Support for Political Change," appeared in December 1992 (coauthored with Ellen Mickiewicz).

A former President of the Midwest Political Science Association, Finifter has served the profession in many positions, including APSA Annual Meeting Program Chair, Chair of APSA's Committee on 